\title{
The Effect of Using Waste Glass [WG] as Partial Replacement of sand on Concrete
}

\author{
K. I. M. Ibrahim \\ Construction Engineering Dept., College of Engineering at Qunfudha, Umm-Al-Qura University - KSA on \\ Sabbatical leave from higher Institute of Engineering and Technology of Kafr-EL-shiekh - Egypt
}

\begin{abstract}
WG produces big environmental problems, because of inconsistency of WG streams. With increasing environmental stress to reduce WG and to recycle it as much as possible, the concrete industry has adopted number of techniques to achieve this goal. The research aim is studying WG influence as Partial sand Replacement on concrete. In this research, sand was replaced by WG powder as 0\%, 5\%, 10\%, $15 \%, 20 \%, 25 \%, 30 \%, 35 \%$ and $40 \%$ by weight. A constant water/cement $=0.45$ and a constant cement content $400 \mathrm{~kg} / \mathrm{m}^{3}$ are used. The samples of concrete were tested at age $=28$ days to specify tensile strength, compressive strength, water absorption and dry density. The research results illustrated that permissibility of using WG as partial sand replacement until $40 \%$ by weight without reduction in tensile and compressive strengths with comparison of control concrete. The best replacement dosage of WG is $15 \%$ which showed about $37 \%$ and $25 \%$ increasing in tensile and compressive strengths of concrete respectively.
\end{abstract}

Keywords: workability, tensile strength and waste glass[WG]

\section{Introduction}

Production of concrete requires many quantities of natural aggregates [1].Using the sand as a fine aggregate will lead to exploitation of normal resources. If sand is replaced by WG by specific dosage, it will decrease sand content and thus reducing the ill effects of sand so making concrete industry sustainable [2]. The quantity of WG produced has increased through the recent years owing to growing requirements of glass products. When WG reused in concrete industry, concrete cost will be decreased[3]. Recycling of WG by transforming it to fine aggregate leads to save landfill place and reduces the extraction demand of natural raw materials for construction sector [4]. Glass is transparent material and used in manufactured products as sheet glass and container glass, it is an perfect material for recycling and its uses save much energy. One of its important contributions is concrete production[5].Because of the alkali-silica reaction (ASR), which causes decrease in durability and also concrete strength, its application is still not common at present time[6]. Glass aggregate is strong but brittle, it has angular shape and relatively smooth texture [7-10]. It is low in shrinkage and water absorption, and it is high in resistance to wear [9]. The using of WG causes the interaction between alkalis in cement and the silica in aggregates which gives silica gel which may be swelled by absorbing water and so the gel volume increases, this swelling generates internal stresses which introduce cracks [11].It was found that the flexural, compressive, and tensile strengths of WG concrete had decreasing tendency with increasing WG ratio [12], also incorporation of $30 \%$ glass powder could be done in concrete without any long term effects [13].It was observed a clear improvement in the WG concrete mixes compressive strength, but the workability reduced when the content of WG increased[14]. The pozzolanic influence of WG is more clear at the later age [28 days] in concrete, the optimum $\%$ of WG which awards the maximum results of flexural and compressive strengths equal to $20 \%$ and using WG powder decreases the ASR expansion[15]. the permissibility of using WG powder as partial sand replacement until $30 \%$ of particle size ranges( $0-1.18) \mathrm{mm}$ was observed, With increasing WG content to $40 \%$ the weight decreases by $5 \%$ and the workability increases with increasing WG content[2]. Using WG enhanced sintering temperature, reduced water absorption. The addition of 30-50\% of WG produced high quality lightweight aggregate with lower density [16].

\section{Materials}

The materials which used in making concrete mixes were examined according to American Standard of Testing Materials ASTM and Egyptian standard Specifications ESS. Basalt with maximum size $=25 \mathrm{~mm}$ and approximately flaky particle shape was used. Natural sand was used in this study. cement was used and its content equal to $400 \mathrm{~kg} / \mathrm{m} 3$ for all mixes . Supper-plasticizer was added to give the water/ cement $=0.45$ with slump equals to $(6-11) \mathrm{cm}$. WG was collected and pulverized in apparatus of abrasion[Los Angeles] and then was sieved through $4.75 \mathrm{~mm}$ sieve . The properties of the cement, aggregates and WG used in this research are illustrated in tables 1 and 
Table[ 1 ] Properties of cement

\begin{tabular}{|l|l|}
\hline Properties & Results \\
\hline Soundness [mm] & 0.9 \\
\hline Initial setting time $[\mathrm{min}]$ & 95 \\
\hline Finial setting time $[\mathrm{min}]$ & 185 \\
\hline Compressive strength $\left[\mathrm{kg} / \mathrm{cm}^{2}\right]$ 3days & 227 \\
\hline Compressive strength[kg/ $\left./ \mathrm{cm}^{2}\right]$ 28days & 472 \\
\hline
\end{tabular}

Table [2] Properties of basalt, sand and WG

\begin{tabular}{|l|l|l|l|}
\hline Property & Basalt & Sand & Waste glass \\
\hline Specific weight & 2.71 & 2.63 & 2.21 \\
\hline Density $\left[\mathrm{t} / \mathrm{m}^{3}\right]$ & 1.76 & 1.71 & 1.42 \\
\hline Absorption \% & 0.61 & - & 0.47 \\
\hline Abrasion value \% & 9.25 & - & - \\
\hline Impact value \% & 5.52 & - & - \\
\hline
\end{tabular}

III CONCRETE MIXES PROPORTION

Table (3) : Concrete Mixes Proportion

\begin{tabular}{|r|r|r|r|r|r|r|r|}
\hline Mix no & $\begin{array}{r}\text { Waste } \\
\text { Glass \% }\end{array}$ & $\begin{array}{r}\text { Waste } \\
\text { Glass } \\
\mathrm{kg} / \mathrm{m}^{3}\end{array}$ & $\begin{array}{r}\text { Cement } \\
\mathrm{kg} / \mathrm{m}^{3}\end{array}$ & $\begin{array}{r}\text { Water } \\
\mathrm{kg} / \mathrm{m}^{3}\end{array}$ & $\begin{array}{r}\text { Basalt } \\
\mathrm{kg} / \mathrm{m}^{3}\end{array}$ & $\begin{array}{r}\text { Sand } \\
\mathrm{kg} / \mathrm{m}^{3}\end{array}$ & $\begin{array}{r}\text { Super } \\
\text { plasticizer } \\
\mathrm{kg} / \mathrm{m}^{3}\end{array}$ \\
\hline 1 & 0 & 0 & 400 & 180 & 1224 & 612 & 4.8 \\
\hline 2 & 5 & 30.6 & 400 & 180 & 1224 & 581.4 & 4.8 \\
\hline 3 & 10 & 61.2 & 400 & 180 & 1224 & 550.8 & 4.8 \\
\hline 4 & 15 & 91.8 & 400 & 180 & 1224 & 520.2 & 4.8 \\
\hline 5 & 20 & 122.4 & 400 & 180 & 1224 & 489.6 & 4.8 \\
\hline 6 & 25 & 153 & 400 & 180 & 1224 & 459 & 4.8 \\
\hline 7 & 30 & 183.6 & 400 & 180 & 1224 & 428.4 & 4.8 \\
\hline 8 & 35 & 214.2 & 400 & 180 & 1224 & 397.8 & 4.8 \\
\hline 9 & 40 & 244.8 & 400 & 180 & 1224 & 367.2 & 4.8 \\
\hline
\end{tabular}

nine mixes were used as following, one mix without waste glass[WG] as a control mix, eight mixes with different contents of (WG) to study the WG content effect on tensile and compressive strengths. These mixes are similar except for WG content. For all mixes the cement quantity was $400 \mathrm{~kg} / \mathrm{m}^{3}$ and the water/ cement = 0.45 by weight. Super-plasticizers per $\mathrm{m}^{3}$ were also used.

\section{Description Of Tested Specimens}

27 cubes of $15 \mathrm{~cm}$ length and 27 cylinders $(15 \mathrm{~cm}$ diameter, $30 \mathrm{~cm}$ height $)$ were cast for compression and tension strengths . Mixes were poured and mechanically compacted inside the forms. The samples were tested by using compression machine which its capacity equals to $2000 \mathrm{KN}$.

\section{Test Results}

\section{Compressive strength}

The compression strength of all mixes are illustrated in figure 1 and table 4 . From the results, it can be noticed that, with increasing of WG content ,the compressive strength is increasing with comparison to control concrete [without WG] and the increase is so great at the dosage $=15 \%$. The maximum concrete compressive strength measured was about $25 \%$ more than control mix at $15 \% \mathrm{WG}$ ratio. the increase of concrete compressive strength was $2.07 \%, 3.79 \%, 24.47 \%, 17.13 \%, 13.11 \%, 12 \%, 6.89 \%$ and $5 \%$ for $5 \%, 10 \%, 15 \%, 20 \%, 25 \%, 30 \%, 35 \%$ and $40 \%$ WG dosage respectively. 
Table [4] Compressive strength $\left[\mathrm{kg} / \mathrm{cm}^{2}\right]$ of concrete after age $=28$ days

\begin{tabular}{|r|r|}
\hline Waste glass content $\%$ & Compressive strength $\left[\mathrm{kg} / \mathrm{cm}^{2}\right]$ \\
\hline 0 & $358.07[\mathrm{control}]$ \\
\hline 5 & $365.48[+2.07 \%]$ \\
\hline 10 & $371.68[+3.79 \%]$ \\
\hline 15 & $445.68[+24.47 \%]$ \\
\hline 20 & $419.23[+17.13 \%]$ \\
\hline 25 & $404.89[+13.11 \%]$ \\
\hline 30 & $401[+12 \%]$ \\
\hline 35 & $382.74[+6.89 \%]$ \\
\hline 40 & $376[+5 \%]$ \\
\hline
\end{tabular}

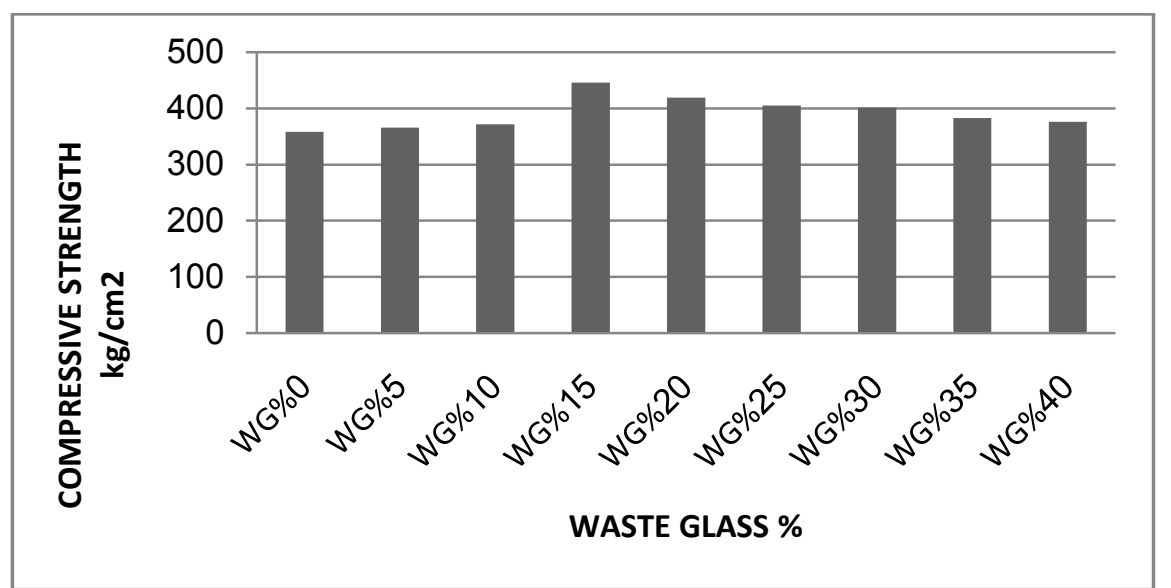

Fig. [1] Compressive strength $\left[\mathrm{kg} / \mathrm{cm}^{2}\right]$ of concrete after age $=28$ days

\begin{tabular}{|l|l|}
\hline Waste glass content \% & Tensile strength $\left[\mathrm{kg} / \mathrm{cm}^{2}\right]$ \\
\hline 0 & $24.13[$ control] \\
\hline 5 & $26.18[+8.5 \%]$ \\
\hline 10 & $27.03[+12.02 \%]$ \\
\hline 15 & $33.04[+36.92 \%]$ \\
\hline 20 & $32.01[+32.66 \%]$ \\
\hline 25 & $29.15[+20.8 \%]$ \\
\hline 30 & $28.13[+16.57]$ \\
\hline 35 & $27.13[+12.43]$ \\
\hline 40 & $26.16[+8.04 \%]$ \\
\hline
\end{tabular}

\section{Tensile strength}

The results are illustrated in table 5 and figure 2. Increasing in tensile strength was observed until $40 \%$ replacement of waste glass with comparison to control concrete [without WG] . The maximum tensile strength measured was about $37 \%$ more than control mix corresponding to concrete mix containing $15 \%$ waste glass. From the results, it can be noticed that,with increasing WG content, the tensile strength increases and the increaseisso great at ratio $=15 \%$.theincreaseof tensile strength was $8.5 \%, 12.02 \%, 36.92 \%, 32.66 \%, 20.8 \%, 16.57 \%, 12.43 \%$ and $8.04 \%$ for $5 \% 10 \%, 15 \%, 20 \%, 25 \%, 30 \%, 35 \%$ and $40 \%$ WG dosage respectively. 
Table [5] Tensile strength $\left[\mathrm{kg} / \mathrm{cm}^{2}\right]$ of concrete after age $=28$ day

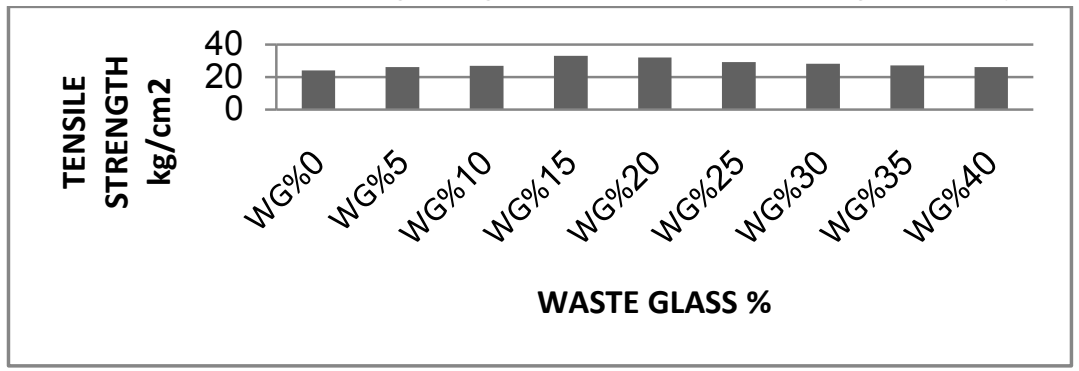

Fig. [2] Tensile strength $\left[\mathrm{kg} / \mathrm{cm}^{2}\right]$ of concrete after age $=28$ days

\section{Slump}

Values of all mixtures slump are represented in fig. 3. The slump increased gradually with increasing the content of WG. Absorption of WG particles is less as compared of sand and thus enhancing the concrete workability. For $40 \%$ WG content, slump was maximum.

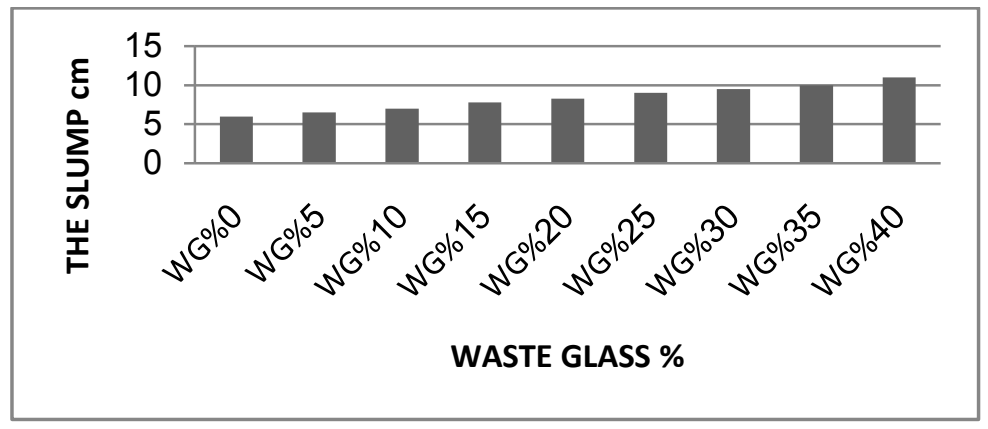

Fig. [3] The values of slump [cm]

\section{Water absorption}

Table[6] illustrates the percentage absorption for all mixtures. From the table,

water absorption percentage decreased with increase of WG content. The lowest value of absorption was found for $40 \% \mathrm{WG}$ content.

Table[ 6] Water absorption results

\begin{tabular}{|r|r|}
\hline WG \% & Water absorption \% \\
\hline 0 & 1.80 \\
\hline 5 & 1.08 \\
\hline 10 & 0.87 \\
\hline 15 & 0.80 \\
\hline 20 & 0.75 \\
\hline 25 & 0.68 \\
\hline 30 & 0.61 \\
\hline 35 & 0.53 \\
\hline 40 & 0.50 \\
\hline
\end{tabular}

Dry density of each mixture was calculated and it was observed that the density decreased with increase in WG content. The results showed about $4 \%$ reduction in dry density of concrete for mix with $40 \%$ WG content as

compared to control mix. Table [7] gives the results of dry density and variation in it with respect to control

Table [7 ] Dry density results

\begin{tabular}{|r|r|}
\hline WG \% & Dry density $\mathrm{kg} / \mathrm{m}^{3}$ \\
\hline 0 & {$[$ control $] 2530$} \\
\hline 5 & {$[-0.44 \%] 2519$} \\
\hline 10 & {$[-0.6 \%] 2515$} \\
\hline
\end{tabular}




\begin{tabular}{|r|r|}
\hline 15 & {$[-1.9 \%] 2482$} \\
\hline 20 & {$[-1.98 \%] 2480$} \\
\hline 25 & {$[-2.02 \%] 2479$} \\
\hline 30 & {$[-3 \%] 2454$} \\
\hline 35 & {$[-3.44 \%] 2443$} \\
\hline 40 & {$[-3.95 \%] 2430$} \\
\hline
\end{tabular}

\section{Conclusions}

1. WG can effectively be used as fine aggregate replacement.

2. Sand can be replaced by WG until $40 \%$ by weight without reduction in tensile and compressive strengths with comparison of control concrete.

$3.15 \%$ replacement of $\mathrm{WG}$ showed about $25 \%$ increase in compressive strength.

4. $15 \%$ replacement of $\mathrm{WG}$ showed about $37 \%$ increase in tensile strength.

5. water absorption percent of concrete decreases with increasing WG content.

6. The best replacement dosage of WG is $15 \%$.

7. Using WG not change the color of concrete.

8. $40 \%$ WG content reduces density by about $4 \%$.

9.At constant super-plasticizer, the workability increases with increasing the WG content.

\section{References}

[1]. Ashutosh Sharma and Ashutosh Sangamnerkar. Glass Powder - A Partial Replacement for Cement?. International Journal Of Core Engineering \& Management (IJCEM) 2015; 1( 11)

[2]. M. Iqbal Malik, Muzafar Bashir, Sajad Ahmad, Tabish Tariq, Umar Chowdhary. Study of Concrete Involving Use of Waste Glass as Partial Replacement of Fine Aggregates. IOSR Journal of Engineering 2013 ; 3(7)

[3]. B. Topcu and M. Canbaz. Properties of Concrete containing waste glass. Cement and Concrete Research 2004; (34) :267-274

[4]. Rakshvir, M., Barai, S.V. Studies on recycled aggregates-based concrete. Waste Management \& Research $2006 ; 24$ (3):225-233.

[5]. S.P. Gautam, Vikas Srivastava and V.C. Agarwal J. Acad. Use of glass wastes as fine aggregate in oncrete. Indus. Res. 2012;1(6).

[6]. Miao Liu. Incorporating ground glass in self-compacting concrete. Construction and Building Material 011;( 25): 919-925

[7]. Chen $\mathrm{CH}$, Huang $\mathrm{R}, \mathrm{Wu} \mathrm{JK}$, Yang CC. Waste E-glass particles used in cementitious mixtures. Cement and Concrete Res 2006;36(3):449-56.

[8]. Park SB, Lee BC, Kim JH. Studies on mechanical properties of concretecontaining waste glass aggregate. Cement and Concrete Research 2004;34(12):2181-2189.

[9]. Taha B, Nounu G. Properties of concrete contains mixed color waste recycled glass as sand and cement replacement. Construction Build Mater 2008;22(5):713-720.

[10]. Topcu IB, Canbaz M. Properties of concrete containing waste glass. Cement and Concrete Researc 2004;34(2):267274.

[11]. Meyer C, Baxter S, Jin W. In: Alkali-silica reaction in concrete with waste glass as aggregate 1996, 1388-1397.

[12]. Park, S.B., Lee, B.C., Kim, J.H. Studies on mechanical properties of concrete containing waste glass aggregate. Cement and Concrete Research 2004; 34 (12):2181-2189.

[13]. Shayan, A., Xu, A. Value-added utilization of waste glass in concrete. Cement and Concrete Research 2004; 34 (1): 81-89.

[14]. Chen, C.H., Wu, J.K., Yang, C.C. Waste E-glass particles used in cementitious mixtures. Cement and Concrete Research 2006; 36 (3):449-456.

[15]. Zainab Z. Ismail *, Enas A. AL-Hashmi. Recycling of waste glass as a partial replacement for fine aggregate in concrete. Waste Management 2009; 29 :655-659

[16]. Bui Le Anh Tuan, Chao-Lung Hwang, Kae-Long Lin , Yuan-Yuan Chen, Mung-Pei Young. Development of lightweight aggregate from sewage sludge and waste glass powder for concrete. Construction and Building Materials 2013;47: 334-339 